\title{
Wal-Mart In The Global Retail Market: Its Growth And Challenges
}

Bahaudin G. Mujtaba, (E-mail: mujtaba@sbe.nova.edu), Nova Southeastern University Simone Maxwell, (E-mail: simomaxw@nova.edu), Nova Southeastern University

\begin{abstract}
The Wal-Mart Corporation is one of those companies that have been impacted by change at all levels as they conduct business and expand their operations throughout the globe. Wal-Mart has also greatly benefited from deeply-held universal values, philosophies, and management practices which have made them successful in diverse countries. In a short span of about forty years, this company has become the envy of any and every major corporation in the world. This case presents how Wal-Mart has achieved this enormous success, its best practice in the global retail industry, international growth trends and challenges, and various lessons that have been learned from their expansion in foreign countries. The case focuses on customer value delivery related to low prices, use of technology, and an organizational culture passionate on continuous learning.
\end{abstract}

\section{INTRODUCTION}

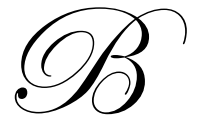

y maintaining its promise to customers of "everyday low prices," Wal-Mart has injured many of its competitors. A new Wal-Mart SuperCenter opens up about every 38 hours (McNally, 2005). Although Wal-Mart, like any other firm, experiences problems and challenges in the workforce, it continues to thrive because they learn from their experiences and change or adapt accordingly. Wal-Mart, in 1962, opened its first Wal-Mart Discount City and now it sells more toys than Toys "R" Us, more clothes than the Gap and Limited, and more food than Kroger and a few other supermarkets combined (Upbin, 2004). If Wal-Mart was its own economy, it would rank $30^{\text {th }}$ right next to Saudi Arabia while growing at the rate of about $11 \%$ each year. The "Wal-Martization" of the world is bringing about good and bad changes to commerce around the globe. Wal-Mart is expected to be the first trillion dollar retailer in the world.

With annual sales of about $\$ 300$ billion, around $68 \%$ of the sales come from Wal-Mart Stores, $19 \%$ from its international operations, and 13\% from its Sam's Club. Wal-Mart's annual profits are about $\$ 10$ billion and they have a market value of over $\$ 250$ with assets worth over $\$ 105$ billion. As of April 2005, in addition to its approximately 4,000 stores in the United States, Wal-Mart had over 815 stores in Mexico, 393 stores in Japan, 322 stores in United Kingdom, 278 stores in Canada, 85 stores in Germany, 54 in Puerto Rico, 60 in China, 293 in Brazil, 16 in South Korea, and 12 stores in Argentina while expanding into these countries on a continuous basis. Currently, it employs over one million people in the United States and nearly half a million individuals internationally; it is the largest private employer worldwide. Furthermore, it ranked $10^{\text {th }}$ on Forbes Leading 2000 Companies in the World based on composite scores for sales, profits, assets, and overall market value. As a matter-of-fact, Wal-Mart ranked first in sales, ranked sixth in total market value, and they ranked eight in overall profits through Forbes ranking of World's 2000 Leading Companies in Forbes April 12, 2004 issue.

To capitalize on the global opportunities, Wal-Mart's international division will need to take action on several different fronts, ranging from enhancing its global procurement capabilities to entering new countries. Despite the challenges, Wal-Mart will undoubtedly emerge as a truly global retailer. That should mean leading market positions in Europe, Japan, and emerging markets - places where Wal-Mart's presence is limited today. Competitors and suppliers around the world will need to prepare to compete in markets that will be shaken and remade by Wal-Mart's global expansion (Wal-Mart International: The Challenge Abroad, 2006) 
Figure 1 - International Wal-Mart Stores And Entry Dates

Wal-Mart International $\quad 2,710$ total units

$\begin{array}{lll}\begin{array}{l}\text { Country } \\ \text { Mexico }\end{array} & \text { Retail Units } & \begin{array}{l}\text { Date of Entry } \\ \text { November } 1991\end{array} \\ \text { Puerto Rico } & 815 & \text { August } 1992 \\ \text { Canada } & 54 & \text { November } 1994 \\ \text { Argentina } & 278 & \text { November } 1995 \\ \text { Brazil } & 12 & \text { May 1995 } \\ \text { China } & 293 & \text { August } 1996 \\ \text { Germany } & 60 & \text { January } 1998 \\ \text { South Korea } & 85 & \text { July 1998 } \\ \text { United Kingdom } & 16 & \text { July 1999 } \\ \text { Japan } & 322 & \text { March 2002 } \\ \text { Costa Rica } & 393 & \text { September } 2005 \\ \text { Guatemala } & 59 & \text { September } 2005 \\ \text { Honduras } & 119 & \text { September } 2005 \\ \text { Nicaragua } & 37 & \text { September } 2005\end{array}$

\section{MANAGEMENT PRINCIPLES IN BUSINESS ENVIRONMENTS}

Management sciences deal with a specific set of concerns which include: quantitative management, operations management, reengineering, total quality management, and management information systems. Wal-Mart has applied quantitative management through its supply chain system for the past three decades and this supply chain application has differentiated them from their competitors to make them a world leader. Wal-Mart employs a sophisticated technology which allows efficient operations, sales tracking, and reduces inventory turnaround by making their suppliers partners as they get the needed information in real time. This supply chain system helps managers and suppliers keep track of goods that are selling, determine how much inventory to have in stock, and identify what products sell the most depending on the season, resulting in better decision making by managers. The operations management systems used by Wal-Mart provide managers the tools needed to perform their job efficiently and to assist managers in making the best decisions. Managers also systematically receive input from their employees to respond to customers' needs and their changing desires. They also oversee the acquisition of inputs, control of conversion processes, and disposal of goods and services to determine where there is a need for improvement. For Wal-Mart owners, this means making sure their decisions will produce the desired goals with minimum labor, expense, and materials. Successful implementation of this system is perhaps the major reason why Wal-Mart is able to offer customers good variety of products and services at affordable prices.

Total Quality Management (TQM) is a concept rooted in the idea of continuous improvement in the operation to reduce cost, increase quality and to serve the needs of customers in the shortest period of time. TQM tools employ and rely on participative management principles centered on empowerment, education of employees, and the needs of customers. TQM focuses on improving the quality of an organization's products and services and stresses that all of an organization's value-added activities should be directed toward this goal. The core concept behind TQM and quality secret is that there is always a better way to get the job done by eliminating the waste associated with the way jobs get done. Wal-Mart has put into practice TQM in various ways within the organization which is seen through the hospitality employees provide to customers as they come into their stores. Wal-Mart also implements TQM by continuously seeking the best products and the lowest prices from national and international suppliers around the globe. In keeping with their promise that the customer is number one, Wal-Mart continues to find ways to exceed the customer's expectations by offering product variety and low prices. By continuing to improve the quality of goods, variety, and the way they are sold, Wal-Mart ensures that their standards remain competitive and their customers remain satisfied. Wal-Mart works closely with partners and suppliers to achieve this and has adapted standards for all of its suppliers to ensure they understand their responsibilities in remaining competitive. Jointly with suppliers in the value chain, they scan and monitor the task and the general environments to stay aware of their customers' changing 
needs and of their competitors' strategies. For example, a task environment at Wal-Mart is composed of forces which stem directly from distributors, suppliers, competitors, and customers. These forces affect the means in which an organization acquires input and its ability to extract outputs. These forces affect managers on a day-to-day basis and therefore have the most direct consequences upon short-term decision making.

\section{Customers}

Customers are and will always be an important force for any organization that directly deals with them since they buy the goods and services produced by an organization thus ensuring its survival. It has been reported that eighty percent of residents of the United States shop at Wal-Mart at least once a year and each week 100 million customers visit Wal-Mart's U.S. stores, about one-third of the U.S. population. Wal-Mart fills the needs of each population, for example, by identifying and focusing on their needs. One example can be observed by seeing and identifying an increase in customer demand for plus-size clothing, Wal-Mart was able to add an additional outlet to attract new customers while offering them what they wanted at low prices. Wal-Mart's strategy for addressing this force was to create a plus-size division increasing its apparel sales nationally and internationally. Its mission was to create a plussize department which was neither demeaning nor insensitive to the customer's feelings. Wal-Mart was able to accomplish this by thoughtfully calling its plus size department "Women's" as well as developing its own sizing category which includes sizes phrased as $14 \mathrm{~W}$ to $28 \mathrm{~W}$.

In addition to meeting the needs of plus size customers, Wal-Mart has effectively utilized the strategy of market segmentation by partnering with National Gay and Lesbian Chamber of Commerce to cater to that group of customers, as well as employees. Bob McAdam, Wal-Mart's Vice President of corporate Affairs, responded that there's a lot of misinformation about our policies and what we stand for, "and noted that the company added gays and lesbians to its antidiscrimination policy and founded an LGBT resource group three years ago" (Henderson, 2006). Additionally, Wal-Mart has continually taken actions to expand its U.S. customer base. On September 7, 2006, the Wall Street Journal reported that Wal-Mart was modifying its U.S. stores from a one-size-fits-all merchandising strategy to a custom-fitting merchandise assortment designed to "reflect each of six demographic groups AfricanAmericans, the affluent, empty-nesters, Hispanics, suburbanites, and rural residents (Wikpedia, 2006). The company has also developed various strategies to keep customers in their stores as long as possible, which include; exclusive concerts by various bands on Wal-Mart TV, plus in store radio and special broadcasts because they believe the more time spent in store, the more money customers spend (McNally, 2006). Therefore, it is safe to say that Wal-Mart is effectively trying to retain and broaden its customer base globally and nationally.

\section{Competitors}

A driving force for Wal-Mart is competition and in the large scale discount stores industry, Target, Kmart and Costco Wholesale are its closest competitors in the United States. Wal- Mart has also positioned itself among other grocery chains such as Kroger, Publix, Safeway, Albertsons, Publix, Winn- Dixie and many other regional chains and independents. Competitors can create many obstacles, such as lower prices, product monopolies, and loss of market share. However, Wal-Mart sells four times more than number-two retailer Home Depot sells in a year and does more business than Target, Sears, Kmart, J.C. Penney, Safeway, and Kroger combined. Integral to its survival is Wal-Mart's awareness of what other competitors are doing to either identify or satisfy customer needs. A surging retail trend which Target identified is the consumer attraction to signature lines sporting either national or private labels such as their Isaac Mizrahi clothing line or the Todd Oldham home furnishings. In order to remain competitive, for example, one of Wal-Mart's strategies has been to eliminate old worn-out brands such as Kathy Lee and Bobbie Brooks and push its new stylish label known as George. The George brand of clothing also has a cost/benefit option because there are no intermediaries that allow margins on the clothing to be significantly lower than other national brands guaranteeing the Wal-Mart business strategy of "Always Low Prices, Always." According to analysts, WalMart apparel for 2004 comprised 20\% of its total sales, making this strategy an effective decision to deal with the competitor force. However, Wal-Mart has struggled in foreign markets, such as Germany, South Korea and China; in July 2006, Wal-Mart announced its withdrawal of operations from Germany because of sustained losses and in China, its strategy of "everyday low prices" has not been successful against "Chinese mom-and-pop" shops that are used to cutthroat pricing. In May 2006, Wal-Mart withdrew from the South Korean market when it agreed to sell all 16 of its 
South Korean outlets to Shinsegae, a local retailer, for \$882 million (Wikpedia, 2006) Overall, competitive comparisons show that Wal-Mart has been out-performing their competitors for many reasons. Also, other relevant reasons for Wal-Mart's high performance can include their vast amount of acquisitions in foreign countries. Wal-Mart has acquired what would be potential competitors such as Bompreco and Sonae which are the major supermarkets in Northern Brazil, this acquisition has led them to have only two major competitors left there, namely Carrefour and Pão de Açúcar (Wikpedia, 2006). Other countries where Wal-Mart has acquired successful chains include Japan, Canada and Mexico.

The general environment at Wal-Mart, similar to other large organizations, includes forces stemming from technological, socio-cultural, demographic, economic, political, legal, and global forces which greatly impact the task environment. These forces tend to be more elusive and more challenging to identify and resolve than the direct forces in the task environment.

\section{Demographics}

Demographic forces are the results of changes either in perceptions, or characteristics of a population such as age, ethnic group, and social class. As the economy becomes more open to globalization, the diversity of customers will also become an important force for this giant retailer's selection of employees, location, products, and marketing strategies. The result of this impact is that Wal-Mart is building stores in more diverse, ethnically dense neighborhoods. In order to attract a variety of local customers, Wal-Mart used the business strategy known as "Store of the Community." This led to the creation of a marketing campaign using commercials with ethnically diverse employees and shoppers, speaking about their personal experiences dubbed in their native tongues. An example where this strategy has been successful is the Wal-Mart Canadian market, at least in Vancouver, which has a multitude of commercials in several languages such as Italian, South Asian, and Cantonese in order to match the native tongue of the local prospects. Also, each Wal-Mart super- center store in the United States is equipped with an international aisle that provides products that caters to ethnicities such as Latinos and Jamaicans, this greatly boosts their market share as these products are difficult to find at other retailers and they are generally priced more reasonably than at other stores. Wal-Mart has also effectively catered to the lower and middle class society by providing cheaper check cashing services and cheaper money wiring services. It is also noted that, all the demographic factors around a particular store go into the merchandising mix; it may look like they carry all the same stock, but they actually don't.

\section{Technology}

Another example of an indirect force which has had a tremendous effect on Wal-Mart is the effective use of the latest in information technology. Wal-Mart used information technology to modernize its stores in the 1970's by integrating bar-code scanners at its registers and involving suppliers in the sharing of information. Logged sales data was then sent to management giving them exact data on purchasing and current stock. This strategy, as a result of effectively using technology, is the Just-In-Time inventory Management system used at Wal-Mart. The Just-In-Time system allows them to store products that are needed and order according to demand which reduces the high cost of inventory storage and purchasing. Wal-Mart also introduced the Radio Frequency Identification RFID technology into its supply operations. The new technology will eventually replace bar codes, help deter theft, and cut costs. RFID uses radio frequencies to transmit data about the merchandise. RFID tags will hold more data than the existing bar codes and unlike bar codes they will not need to be scanned by hand. The technology has not been perfected yet, so WalMart is taking a bit of risk to be one of the first retailers implementing it. As evidence of Wal-Mart's commitment to the RFID technology, Wal-Mart required its top 100 suppliers to begin using it as of January 2005.

Consequently, Wal-Mart has also remained innovative in foreign markets by means of new technology. WalMart Canada has launched PhotoBooks, a state-of-the-art photo product that gives customers the ability to create exquisite "coffee table" books using their favorite images through the Wal-Mart Photo Centre Online website. PhotoChannel's new flash rendering technology sets Wal-Mart PhotoBooks apart from their competition and offers consumers advanced features to create picture perfect memories. By providing leading edge products like PhotoBooks they continue to deliver to their customers one of the best online ordering experiences (Market Wire, 2006). 


\section{VALUE DELIVERY PRACTICES IN WAL-MART}

With Sam Walton's philosophy on delivering value, Wal-Mart has become a national and international success in less than four decades from its inception because they deliver value for all of their relevant stakeholders. The strides that Wal-Mart has taken in the retail and grocery industries and the fast pace at which it has excelled has never been seen before by any other retail corporation on such a massive scale. In a short span of about forty years, this company has become the envy of many major corporations in the world. By maintaining its promise to customers of "everyday low prices," it provides unbeatable value for current and prospective customers. Wal-Mart, a Delaware corporation, has its principal offices in Bentonville, Arkansas. In 1962, the first Wal-Mart Discount City store was opened. In 1984, the Company opened its first three Sam's Clubs, and in 1988, its first Wal-Mart Super Center (combination full-line supermarket and discount store).

In 1992, the Company began its first international initiative in order to provide the same value and low prices on a global scale. The Company's international presence has continued to expand, and is growing faster than ever across the globe. Jointly, the sales from the countries of Canada, Mexico, and the United Kingdom make up about 80\% of its international revenues. Wal-Mart's international sales make up about one-fifth of its overall revenues; their international sales division has enjoyed an enormous success and does not seem to be losing momentum, despite some temporary challenges and setbacks. As mentioned before, Wal-Mart has been the fastest growing and largest private employer in the United States. According to Upbin (2004), the Wal-Martization of the world is bringing about good and bad changes to commerce around the globe. Due to its relentless vision for low prices, more and more manufacturing jobs are moving to developing economies, such as China, leaving United States workers unemployed. On the other hand, international commerce through Wal-Mart will create "over 800,000 jobs worldwide over the next several years, not to mention the labor needed to build the stores, parking lots and distribution centers" (Upbin, 2004). Wal-Mart is expected to be the first trillion dollar retailer in the world. Wal-Mart has become what it is due to its national and international operations which show an organization that is both effective and efficient in pursuit of providing low prices for customers. Wal-Mart has been consistently rated as the number one efficient retailer in the world. The application and realization of their slogan "Always Low Prices, Always" is perhaps one of the main reasons for its success at home and abroad. Wal-Mart partners with efficient suppliers to provide consumers with quality goods at affordable prices in their stores.

Wal-Mart's founding philosophy and the implementation of successful leadership skills and management strategies have led to its global success. One can easily expand on some of the strategies that have brought them enormous success and opportunities in today's competitive world of retail business. Some of Wal-Mart's highlights are the following:

- Wal-Mart employs over one million people in the United States and around half million individuals internationally.

- It ranked $10^{\text {th }}$ on Forbes Leading 2000 Companies in the World based on a composite scores for sales, profits, assets, and overall market value. As a matter-of-fact, Wal-Mart ranked first in sales, ranked sixth in total market value, and they ranked eight in overall profits through Forbes ranking of World's 2000 Leading Companies in Forbes April $12^{\text {th }}$ issue.

- Wal-Mart is recognized as one of the leading employers of individuals with disabilities in the United States. In the 2002 annual poll by CAREERS FOR THE DISABLED magazine, named Wal-Mart first among all U.S. companies in providing opportunities and a positive work environment for people with disabilities.

- Wal-Mart is one of the leading employers of senior citizens in the United States, employing more than 170,000 associates who are 55 years of age and older.

- $\quad$ Wal-Mart received the Hispanic National Bar Association (HNBA) 2002 Corporate Partner of the Year Award for its consistent support and best practices in the area of diversity.

- $\quad$ Wal-Mart is the leading private employer of emerging groups in the United States. More than 160,000 African American associates and more than 105,000 Hispanic associates work for Wal-Mart.

- Wal-Mart received the 2002 Ron Brown Award, the highest Presidential Award recognizing outstanding achievement in employee relations and community initiatives. 
- $\quad$ The National Action Network (NAN) presented Wal-Mart with the 2002 Community Commitment Corporate Award in recognition of community involvement and diversity practices.

Wal-Mart provides value for its customers through low prices. There are many value drivers that have an effect on Wal-Mart's operations, progress, and success. An assessment of the most relevant value drivers can be seen by looking at their customers, employees, external cultures, suppliers, and competitor values. The following paragraphs explore a few of the relevant stakeholders and their values.

Customer values require managers to keep their finger on the pulse of customers since their needs and desires may change often and since customer service is important to create customer value. At the heart of Wal-Mart's success and growth is the unique culture that Sam Walton built. His business philosophy was based on the simple idea of making the customer feel that $\mathrm{s} / \mathrm{he}$ is number one. He believed that by serving the customer's needs first, his business would also serve its associates, shareholders, communities, and other stakeholders. Wal-Mart's culture has always stressed the importance of customer service. Its associate base across the nation is as diverse as the communities in which they work. This allows Wal-Mart to provide the service expected from each individual customer that walks into their stores expecting low prices. Thus, creating value for customers is Wal-Mart's strongest value-adder. Wal-Mart's commitment to providing customer value is inherent in one of its core beliefs of "Service to Our Customers" passed on to employees as they become oriented to the culture of each store. As part of this commitment, Wal-Mart has set a goal of exceeding customer's expectations with what Sam Walton coined "aggressive hospitality." Wal-Mart wants its Associates to exceed customer expectations with friendly attitudes and an eagerness to assist customers. As part of exceeding customer expectations, Wal-Mart has also instituted the Ten Foot Rule which has been practiced by many retailers in the past two decades including Publix in the state of Florida. The Ten Foot Rule encourages associates to greet customers and offer assistance whenever customers are within ten feet of the associate. Furthermore, Wal-Mart provides value to its customers through its pricing philosophies. The slogan: "Always Low Prices. Always" that appears on its ads alludes to this goal. Wal-Mart provides consumers with quality goods at an affordable price. WalMart's pricing philosophies include the Everyday Low Price (EDLP), Rollback and Special Buys philosophies. WalMart's goal is to pass its savings onto the customer and achieve a profit through the volume of sales generated as a result of lower prices and repeat customers.

External cultural values include all those values outside the organization that may have an impact upon it, beginning with the values of the local community. Wal-Mart's commitment to people means that it also takes its responsibility as a corporate neighbor seriously. Local Wal-Mart stores have made a difference in their communities by:

a) Educating the public about recycling and other environmental concerns via a "Green Coordinator," a specially trained associate who coordinates efforts to make each store environmentally responsible.

b) Raising funds for local children's hospitals via the Children's Miracle Network Telethon.

c) Sponsoring a Community Matching Grant program that involves fund-raising efforts by a nonprofit organization with the participation of Wal-Mart associates.

d) Underwriting college scholarships for high school seniors.

Wal-Mart's community involvement approach is unique and it is guided by associates who live in the local area and understand its needs. Wal-Mart associates combine financial and volunteer support to assist organizations that make a positive difference in local communities. In addition, Wal-Mart has launched several national efforts to help the larger U.S. community.

Some neighborhoods do not welcome Wal-Mart into their communities due to its negative impact on the local merchants and the diversity of available local businesses, in addition to the risk of environmental problems. For example, some local residents opposed a proposal to open a new Wal-Mart store in Inner Grove Heights. In addition to the impact on local businesses, Wal-Mart's low wages and large building design were questioned. Some of the local residents believed that Wal-Mart's presence would change the rural suburban nature of the community and drive out smaller businesses. In Minnesota, Wal-Mart agreed to change its building design to alleviate concerns about the look and size of the building. Before Wal-Mart can fulfill its commitment of giving back to the community it must have the 
support of the community. Also, environmentalists complain that the company's stores often on the outskirts of rural communities eat up open space, replacing farms and forests with concrete and pavement and the company has been fined repeatedly in recent years by various agencies for environmental negligence. Some of Wal-Mart's fines include \$1.15 million to the state of Connecticut for the improper storage of pesticides and toxins that polluted streams near its store, while a year earlier Florida fined the company $\$ 765,000$ for violating storage tank laws at its auto service center (Jones, 2006). However, Wal-Mart is cognizant of the environmental problems that they face, so, they are considering strategies such as powering facilities and fleets with renewable energy, cutting back on waste selling green products, as well as developing plans to offer organic produce and use local farms to save transportation costs. Thus, when picking new locations for stores, Wal-Mart considers the wants and needs of that community.

Suppliers in Wal-Mart reflect many of the sensitivities of the global community, and meets its suppliers', customers', and shareholders' expectations about how they conduct business. The three pillars of Wal-Mart's foundation - respect for the individual, striving for excellence, and customer service - constantly challenge Wal-Mart to deliver best practices and require the same from its suppliers. The way Wal-Mart conducts its business, as well as the manner in which its suppliers conduct their business, impacts Wal-Mart's reputation among its customers and shareholders. Wal-Mart has created standards for suppliers that want to conduct business with them. Based on these standards, suppliers, their contractors, and their subcontractors must conform to the ethical standards and business practices stated in the contract. Wal-Mart regularly monitors the factory base of its suppliers to ensure compliance with the legal requirements and standards in the jurisdictions in which they conduct business. This includes labor and compensation laws, health and safety laws, and environmental laws. If the jurisdiction's legal requirements exceed industry standards, Wal-Mart requires its suppliers to conform to the laws of the jurisdiction in which it is operating. Wal-Mart depends on its suppliers to provide goods and services in a timely manner at a low cost. Doing business with Wal-Mart provides suppliers with an opportunity to increase sales and market share. Wal-Mart is also known for improving the efficiency of its suppliers by insisting that suppliers match Wal-Mart's ability to move and track goods. As an example, in January 2005, Wal-Mart required its top 100 suppliers to implement radio frequency identification (RFID) tags on its merchandise. This new technology is an inventory tracking system that tracks merchandise from the supplier to the store. Wal-Mart has been accused of applying major pressure on its suppliers to reduce costs or risk losing Wal-Mart's business. This criticism is a potential value-destroyer for Wal-Mart and the suppliers. Some suppliers must increase efficiency as well as reduce jobs to meet the cost cutting demands of Wal-Mart. Even through sales increase, the suppliers experience a loss in profits due to the price cutting. In some cases, claim the critics of Wal-Mart, the reduced profits and job loss may negatively impact the suppliers and reduce the benefits of the increased sales and market share. Wal-Mart must also consider how their relationships with their suppliers may impact customer's perception from a public relation's perspective.

Individual values involve the employee's personal values, and are very important since it could have a major impact on the organization's continued success. Careful selection of employees whose personal values closely match those of the organization is essential to an organization's success. Wal-Mart depends on its employees to achieve its goal of exceeding customer expectations with high levels of service. According to Pohlman and Gardiner, an organization's value over time is maximized when the individual employee's values match those of the organization. Wal-Mart hires employees with values congruent to the organization so that Wal-Mart, the customer, and the employees can jointly create value for everyone involved. The associates play an important role in Wal-Mart's success as they maximize value over time for relevant stakeholders. Wal-Mart associates know it is not good enough to simply be grateful to their customers for shopping at their stores - they demonstrate their gratitude in every way they can. They understand that doing so is what keeps their customers coming back to Wal-Mart. This philosophy was noted by Sam Walton who believed that if the organization expected the employees to take care of the customers, then the organization would have to take care of the employees, representing a reciprocal relationship. As stated before, he believed in an inverted pyramid structure with the associates on top, and the "back office support" personnel on the bottom. Wal-Mart has an open door policy where associates are encouraged to bring suggestions to their supervisors on how to make the organization more successful. Wal-Mart also provides its employees with benefits such as profit sharing, 401K plans, medical and health benefits. Since the inception of Wal-Mart's profit sharing plan in 1972 and the inception of Wal-Mart's 401(k) plan in 1997, Wal-Mart has contributed over \$3 billion toward the retirement funds of its associates. 
Wal-Mart has been able to successfully build a competitive advantage through efficiency, innovation, quality, responsiveness to customers, and other factors while some of their competitors have lagged behind in many areas possibly due to complacency and avoidance of integrating technology in a timely manner into their work processes. Wal-Mart has also hired a diverse workforce into its organization to keep pace with the changing consumer demographics. Lastly, it has expanded its operations globally and increased its presence in the U.S. with the addition of new stores as well as through non-traditional advertising on the World Wide Web.

\section{SUMMARY}

Upbin (2004) stated that, for Wal-Mart, "Europe has proven at times adept, at times inept, at acquiring. In China, it struggles with a dauntingly primitive supply chain. In Japan it is taking rice-grain-size steps so as not to damage a powerful but backward retail ecosystem...it...stumbled among stronger competitors in the huge markets of Brazil and Argentina." Wal-Mart entered Hong Kong and two years later left due to mistakes in merchandise selection and location. It left Indonesia in less than two years after its entry in 1996 because one of their stores in Jakarta was looted during the riots. Furthermore, Wal-Mart made mistakes in Germany, South Korea, Brazil, and other international locations, but due to its distaste for repeating mistakes, Wal-Mart managers learn and adjust quickly to changing circumstance. Certainly, Wal-Mart has limitations and learning curves as they compete with local, national and international competitors that are small and large. Yes, they too can learn from others as they adjust to bring about low prices to more consumers around the globe. Yet, many smaller competitors, focused on uniquely delivering better overall value, are successfully growing despite Wal-Mart's success with their customers. Overall, Wal-Mart has shown that it is keeping its momentum for creating superior value by offering an organizational culture that is passionate about reducing cost and offering lower prices.

\section{DISCUSSION QUESTIONS}

1. Will Wal-Mart be the first trillion dollar global retailer? What are your predictions?

2. Who are some of Wal-Mart's global competitors in the retail industry?

3. How has Wal-Mart used technology to boost sales and increase revenue?

4. Discuss how value-driven principles can assist Wal-Mart's managers.

5. $\quad$ Describe some challenges Wal-Mart faces in foreign countries.

6. List some strategies that Wal-Mart utilizes for customer retention.

\section{REFERENCES}

1. Henderson, William. (2006). Wal- Mart puts on a gay-friendly face. The Advocate Report. Retrieved September, 282006 from:http://0proquest.umi.com.novacat.nova.edu/pqdweb?index.

2. Jones, Sara. (2006). Earth Talk. The Current, Nova Southeastern University. October, 92006.

3. Market Wire. (2006). Wal-Mart Canada and PhotoChannel Networks Inc. Launch State-of-the-Art Photo Books; Photo Books feature new flash rendering technology. Retrieved October 4, 2006 from http://0web.lexis-nexis.com.novacat.nova.edu/universe/document

4. $\quad$ McNally, Terrence. (2005). United States of Wal-Mart. Retrieved October 11, 2006 from http://www.organicconsumers.org/BTC/USofwalmart092205.cfm.

5. Mujtaba, B. G. (April 2007). Cross cultural management and negotiation practices. ILEAD Academy Publications; Florida, United States. ISBN: 978-0-9774211-2-1. Website: Ileadacademy.com.

6. Mujtaba, B. G. (2006). Cross Cultural Change Management. ISBN: 1-59526-568-6. Llumina Press, Tamarac, Florida. Website: http://www.llumina.com/store/cccm.htm or www.Llumina.com. Toll free phone: (866) 2299244 or Reg. (954) 726-0902.

7. Wal-Mart Corporation (2004). Hoover’s Company Information. Retrieved April 10, 2004 from http://cobrands.hoovers.com/global/cobrands/proquest/ops. xhtml?

8. Wal-Mart Corporation (2003, October 29). Wal-Mart Named America's Largest Corporate Cash Giver. Wal-Mart News. Retrieved March 30, 2004 from http://www.walmartstores.com/ wmstore/wmstores.

9. Wal-Mart International: The Challenge Abroad. (2006). Retrieved October, 112006 from: http://www.mindbranch.com/products/R402-38.html . 
10. Wal-Mart Facts. (2006). International Operational Data Sheet - August 2006. Retrieved October 4, 2006 from http://www.walmartfacts.com/articles/4378.aspx .

11. Wal-Mart Stores (2004), Home page. Retrieved April 9, 2004 from http://www.walmartstores.com/wmstore/wmstores/HomePage.jsp.

12. Walton, S. and Huey, J. (1992). Made in America. New York: Doubleday.

13. Wikpedia. (2006). Wal-Mart competition and customer base. Retrieved October 3, 2006 from http://en.wikipedia.org/wiki/Wal-Mart\#Competition.

14. Upbin, Bruce (2004). Wall to Wall Wal-Mart: The Retailer Conquered America and Made it Look Easy. The Rest of the World is a Tougher Battleground. Forbes: The World's 2000 Leading Companies. April 12, 2004 issue.

\section{NOTES}


NOTES 